\title{
HIPERURISEMIA DAN RESPONS IMUN
}

\author{
Aaltje E. Manampiring \\ Bagian Kimia Fakultas Kedokteran Universitas Sam Ratulangi Manado \\ Email: aldakussoy@yahoo.com
}

\begin{abstract}
Hyperuricemia, a highly prevalent condition in adult population, is associated with hemodynamic and metabolic disturbances. Albeit, pathophysiological aspects of hyperuricemia are still not clearly understood. Uric acid plays an essential role in immunity by induction of some cytokines and chemokines, such as TNF $\alpha$, Il-1 $\beta$, IL-6, CXCL8 (IL-8), and CXCL1 (growth-related oncogene $\alpha$ ). Deposits of monosodium urate crystals in joint cavities and periarticular tissues are related to an autoinflammatory disturbance, namely gout.
\end{abstract}

Keywords: hyperuricemia, monosodium urate crystal, immune responsse

\begin{abstract}
Abstrak: Hiperurisemia merupakan suatu keadaan yang umum dijumpai pada populasi dewasa dan berhubungan dengan kelainan metabolik dan hemodinamik. Aspek patofisiologik dari hiperurisemia belum sepenuhnya dipahami dengan jelas. Asam urat berperan penting dalam imunitas dengan menginduksi berbagai sitokin dan kemokin, antara lain TNF $\alpha$, Il-1 $\beta$, IL-6, CXCL8 (IL-8) dan CXCL1 (growth-related oncogene $\alpha$ ). Deposit kristal monosodium urat di dalam rongga sendi dan jaringan periartikuler berkaitan dengan gangguan autoinflamasi yang dikenal sebagai gout.
\end{abstract}

Kata kunci: hiperurisemia, kristal monosodium urat, respons imun

Sebutan asam urat (2,6,8-trioxypurine) pertama kali dikemukakan oleh George Pearson pada tahun 1795. ${ }^{1}$ Asam urat merupakan hasil akhir katabolisme purin dalam tubuh. Kadarnya dalam darah bervariasi menurut umur dan jenis kelamin. $\mathrm{Pa}-$ da masa kanak-kanak kadarnya lebih rendah dibanding masa dewasa. Pada laki-laki masa pubertas, kadar asam urat meningkat mendekati nilai orang dewasa dari 3,5 $\mathrm{mg} / \mathrm{dL}$ ke 5,0 mg/dL. Pada perempuan kadar asam urat berkisar 4,0 $\pm 2,0 \mathrm{mg} / \mathrm{dL}$ dan cenderung meningkat sesuai umur, mendekati kadar asam urat pada pria dewasa. Peningkatan ini terutama pada masa menopause dan cenderung menetap. ${ }^{1-5}$

Kadar asam urat dalam darah ditentukan oleh keseimbangan antara produksi dan ekskresi. Bila keseimbangan ini terganggu maka dapat menyebabkan terjadinya peningkatan kadar asam urat dalam darah yang disebut hiperurisemia. ${ }^{6-7}$ Hubungan hiperurisemia dengan penyakit telah lama diketahui, yaitu sejak abad 15 sebelum masehi. ${ }^{1}$ Sekarang ini hiperurisemia banyak dihubungkan dengan: diabetes mellitus, autisme, penyakit pembuluh darah otak, hipertensi pulmoner, polisitemia, hipertensi, penyakit kardiovaskuler, penyakit ginjal dan kadar trigliserida. Secara klinis hiperurisemia mempunyai arti penting karena dapat menyebabkan artritis pirai, nefropati asam urat, tofi, dan nefrolitiatis. ${ }^{8,13}$ Sampai saat ini masih terjadi perdebatan apakah asam urat merupakan faktor risiko yang penting terhadap penyakit kardiovaskuler, walaupun beberapa hasil penelitian menunjukkan bahwa hiperurisemia merupakan salah satu faktor resiko yang penting bagi penyakit kardiovaskuler. ${ }^{13-16}$ Hasil penelitian-penelitian ini telah didukung oleh berbagai penelitian lainnya untuk melihat 
hubungan antara asam urat dengan hipertensi, obesitas, penyakit ginjal dan penyakit kardiovaskuler. Bulakumar et $\mathrm{al}^{17-}$ dalam penelitiannya menyatakan bahwa hiperurisemia merupakan faktor risiko terhadap patogenesis disfungsi endotel vaskuler, juga adanya keterlibatan mekanisme sinyal yang memengaruhi patogenesis tersebut. ${ }^{17}$

Dewasa ini telah dikemukakan bahwa terjadinya gout dihubungkan dengan respons imun. Kristal asam urat dapat menginduksi pelepasan berbagai sitokin dan kemokin seperti TNF $\alpha$, IL-1B, IL-6, IL-8 dan growth-related oncogene $\alpha$, yang memicu terjadinya serangan gout.

\section{HIPERURISEMIA DAN METABOLIS- ME ASAM URAT}

Asam urat telah diidentifikasi lebih dari dua abad yang lalu, namun sampai saat ini beberapa aspek patofisiologinya belum dipahami dengan jelas. ${ }^{5}$ Sebagian besar asam urat disintesis di dalam hati dan hanya sebagian kecil (3-5\%) dilepaskan ke dalam sirkulasi dan berikatan dengan protein pada $\mathrm{pH}$ fisiologis, dan sisanya akan difiltrasi di glomerulus. ${ }^{1,4,6}$

Asam urat merupakan hasil akhir dari metabolisme purin melalui jalur metabolisme biokimiawi yang kompleks. ${ }^{1-5}$ Proses pembentukan asam urat sebagian besar berasal dari metabolisme nukleotida purin endogen, guanylic acid (GMP), inosinic acid (IMP), and adenylic acid (AMP). Reaksi ini dikatalisis oleh enzim xanthine oxidase yang mengubah intermediate hypoxanthine dan guanine menjadi xanthine, dengan hasil akhir asam urat (Gambar 1).
Asam urat tidak bisa dimetabolisme lebih lanjut dan hanya bisa diekskresi sebagian besar lewat ginjal, dan hanya 30\% dapat diekskresi lewat saluran cerna dengan bantuan bakteri usus. ${ }^{4,9}$

Asam urat difiltrasi secara bebas $(100 \%) \mathrm{di}$ dalam glomerulus dan sebagian besar akan direabsorbsi $( \pm 89-100 \%))^{4,7,8}$ Selanjutnya asam urat akan disekresi ke dalam tubulus proksimalis kemudian ke dalam lengkung ansa Henle. ${ }^{5,6}$ Di dalam tubulus kontortus distalis, sebagian akan di- absorbsi kembali (40-44 \%) dan sisanya (6-12 \%) akan diekskresikan melalui urin. ${ }^{4,6}$ Tubulus proksimal merupakan tempat ter-jadinya proses reabsorbsi dan sekresi. Seba-gian besar asam urat direabsorbsi di seg-men pertama tubulus proksimal dan dise-kresi ke segmen kedua tubulus proksimal dengan kecepatan yang lebih tinggi dari reabsorbsi. Pada saat reabsorbsi setelah se-kresi di tubulus yang lebih distal, kira- kira 10\% asam urat yang difiltrasi akan terlihat di urin. ${ }^{1,4,7,8}$ Dari tubulus proksimal yang merupakan tempat transpor, asam urat akan melewati membran apikal yang diperantarai oleh penukar urat atau anion melalui saluran yang peka terhadap listrik. Anion organik seperti laktat menurunkan sekresi urat melalui mekanisme kompetisi transpor. ${ }^{7}$ Penghambatan transportasi urat atau tak efisiennya sekresi tubulus secara genetik dan penurunan filtrasi atau peningkatan absorbsi di tubulus proksimal dapat menyebabkan hiperurisemia. ${ }^{4,5,7}$

Asam urat banyak terdapat pada cairan ekstrasel dan cairan sendi. Sebanyak 98\% terdapat sebagai monosodium urat (MSU) pada $\mathrm{pH} 7,4 .^{6,7,9}$ Plasma tersaturasi dengan

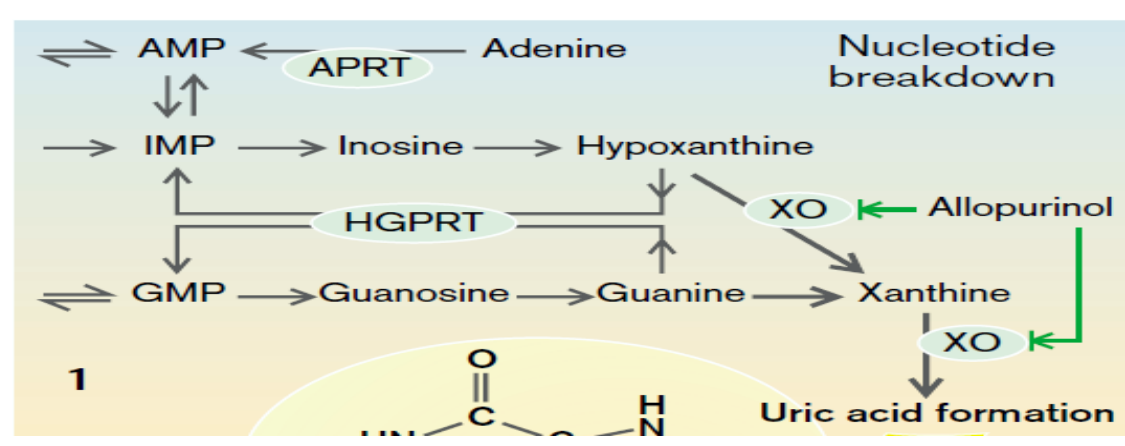

Gambar 1: Sintesis asam urat. Sumber: Silbernagl \& Lang, 2000. 9 
MSU pada konsentasi 6,8 mg/dL.6,7 Asam urat relatif tidak mudah larut dan cenderung mengendap bila terdapat dalam konsentrasi tinggi. ${ }^{11}$

Hiperurisemia adalah keadaan dimana darah seseorang mengandung kadar asam urat di atas nilai normal. ${ }^{11}$ Kriteria hiperurisemia menurut Council for international organization of medical sciences (CIOMS) yaitu > 7mg/dL untuk laki-laki dan > 6 $\mathrm{mg} / \mathrm{dL}$ untuk perempuan. ${ }^{12}$

Terjadinya hiperurisemia disebabkan oleh: ${ }^{4,5}$

1. Produksi yang meningkat: Penyebabnya ialah idiopatik, defisiensi enzim hypoxanthine-guanine phos-phoribosyltransferase (HGPRT) sebagian atau komplet, superaktivitas enzim 5'phosphoribosyl-1'-pyrophosphate

$(P R P P)$ sintetase, konsumsi purin yang berlebihan, peningkatan turnover asam nukleat, tumor lysis syndrome, dan glycogenoses (glycogen storage disease). ${ }^{3,5,7}$

2. Penurunan ekskresi asam urat: Penyebabnya ialah idiopatik, penurunan fungsi ginjal, sindroma $\mathrm{X}$, metabolik asidosis (ketoasidosis atau laktat asidosis), dehidrasi, diuretik, hipertensi, hiperparatiroid, hipotiroid, pre-eklampsi dan eklampsi, obat-obat, serta intoksikasi timah hitam $(\mathrm{Pb})$.

3. Kombinasi keduanya seperti alkoholik, defisiensi glukosa 6 fosfatase, defisiensi fruktosa 1 fosfat aldolase.

Hiperurisemia pada temperatur $37^{\circ} \mathrm{C}$ memudahkan terjadinya saturasi asam urat yang berpotensi menyebabkan terjadinya pengendapan kristal asam urat. ${ }^{6,7}$ Kristalisasi asam urat terjadi lambat, berlangsung beberapa minggu sampai bulan serta dapat mengendap pada cairan sendi, tulang, kulit, dan tendon. ${ }^{8}$ Penumpukan kristal MSU pada persendian dan jaringan periartikuler berhubungan dengan gangguan autoinflamasi yang dikenal sebagai gout. ${ }^{7,11}$

Dewasa ini hiperurisemia sering dihubungkan dengan penyakit kardiovaskuler, hipertensi, penyakit ginjal dan sindrom metabolik. Sejak akhir abad ke-19 telah dilakukan penelitian untuk melihat hubunganhubungan tersebut dan telah dibuat hipotesis bahwa asam urat mungkin merupakan penyebab dari hipertensi dan penyakit ginjal, ${ }^{13}$ namun masih terjadi perdebatan apakah asam urat merupakan faktor risiko yang penting terhadap penyakit kardiovaskuler. Menurut The Joint National Committee on prevention, detection, evaluation, and treatment of high blood pressure, American Heart Association dan National Kidney Foundation, asam urat bukan merupakan faktor risiko, ${ }^{14}$ walaupun terdapat beberapa hasil penelitian yang menunjukkan bahwa hiperurisemia merupakan faktor risiko yang penting bagi penyakit kardiovaskuler. ${ }^{13-14}$ Hasil penelitian ini telah didukung oleh berbagai penelitian lainnya untuk melihat hubungan antara asam urat dengan hipertensi, obesitas, penyakit ginjal dan penyakit kardiovaskuler. Heinig dan Johnson $^{14}$ menyatakan bahwa kira-kira $70 \%$ penderita dengan hiperurisemia mengalami obesitas, $50 \%$ dengan hipertensi, 10 $25 \%$ meninggal akibat penyakit ginjal dan sekitar 20\% meninggal akibat komplikasi kardiovaskuler. Selama ini hiperurisemia telah diidentifikasi bersama-sama atau dianggap sama dengan gout, namun saat ini asam urat telah diidentifikasi sebagai marker untuk sejumlah kelainan metabolik dan hemodinamik. ${ }^{5,15,16}$ Bulakumar et al, ${ }^{17}$ dalam penelitiannya menyatakan bahwa hiperurisemia merupakan faktor risiko terhadap patogenesis disfungsi endotel vaskuler, serta adanya keterlibatan mekanisme sinyal yang memengaruhi patogenesis tersebut.

\section{HUBUNGAN HIPERURISEMIA DAN RESPONS IMUN}

Beberapa penelitian telah dilakukan untuk melihat peranan asam urat sebagai faktor resiko terhadap penyakit kardiovaskuler tetapi hasilnya masih kontroversial. Pillinger et al $^{18}$ mengatakan bahwa asam urat tidak hanya merupakan produk akhir untuk diekskresi namun memberikan beberapa keuntungan biologik. Rock ${ }^{19}$ dalam 
penelitiannya menemukan bahwa asam urat berperan penting pada imunitas.

Telah dipahami bahwa bila sistem imun terpapar oleh zat yang dianggap asing maka akan memberikan dua jenis respons imun yang mungkin terjadi yaitu: respons imun non spesifik atau imunitas bawaan (innate immunity) dan respons imun spesifik (adaptive immunity). Adaptive immunity merupakan respons spesifik humoral dan seluler yang berkembang setelah terjadi pemaparan dengan antigen. Adaptive immunity memiliki memori yang dapat meningkatkan respons terhadap pemaparan berulang dari antigen yang sama. Sebaliknya innate immunity merupakan garis pertahanan non spesifik utama yang yang mendeteksi patogen dan menyusun respons imun serta tidak memerlukan pemaparan terlebih dulu dengan antigen, sebagai contoh kulit, lapisan mukosa, asam lambung dan sel-sel fagosit. ${ }^{20}$

Sejak kurang lebih 10 tahunan yang lalu, para ilmuwan menemukan beberapa pemahaman baru pada respons imun bawaan yang melibatkan sel-sel fagosit seperti makrofag dengan kapasitas untuk mengenal patogen-patogen asing. Makrofag akan menyampaikan kepada reseptor yang mengenal molekul patogen seperti lipopolisakarida (LPS). Reseptor tersebut seperti toll-like receptors (TLRs) akan mendeteksi susunan dari patogen ekstrasel. $^{21}$ Asam urat ternyata dapat dilepaskan atau dihasilkan dari sel-sel yang mengalami cedera dan dapat bekerja sebagai adjuvant signal terhadap sistem imun. Dari hasil penelitiannya, Kanevets et $\mathrm{al}^{22}$ mengemukakan bahwa terdapat suatu faktor yang menentukan terbentuknya endapan asam urat dan berkemampuan sebagai ajuvan endogen. Hal ini menunjukkan bahwa pada patogenesis artritis gout terdapat suatu mekanisme dan aktivasi imun yg diinduksi oleh asam urat. Shi et al ${ }^{19}$ mengatakan bahwa asam urat merupakan suatu sinyal yang berbahaya yang dilepaskan oleh sel-sel yang mengalami kematian, dan hal ini merupakan salah satu di antara berbagai efek biologik asam urat.

Kristal asam urat (monosodium urat:
MSU) yang diperantarai oleh respons imun, merupakan penyebab gout yang saat ini mendapat perhatian di bidang kedokteran. Hal ini pun menjadi perhatian bidang imunologi karena ternyata dapat memediasi sinyal berbahaya (danger signal) dan melibatkan berbagai proses imunologi. ${ }^{19,23}$

Proses inflamasi pada gout dibagi atas dua fase yaitu: $:^{24}$

1. Fase maturasi interleukin-1 $\beta$ (IL-1 $\beta$ ) yang melibatkan sel-sel fagosit seperti monosit masuk ke dalam sendi bersama dengan kristal MSU dan selanjutnya mengaktivasi inflamasom NALP3 $\{($ cryopyrin $)$ a protein that in humans is encoded by the NLRP3 (Nucleotide Oligomerization Domain: NOD-like receptor family, pryin domain containing 3) gene \} untuk menjaga lingkungan sekitar melalui pengolahan dan pelepasan IL-1 $\beta$ dalam bentuk aktif. ${ }^{24}$ Fase ini tidak melibatkan MyD88 atau TLRs.

2. Fase memperoleh IL-1 $\beta$ yang berhubungan dengan respons inflamasi yang dipicu oleh Il-1R dan MyD88 \{(Myeloid differentiation primary response gene (88)\} akan mengaktivasi sel-sel bukan berasal dari sum-sum tulang untuk memroduksi kemokin dan mediator inflamasi yang menyebabkan masuknya netrofil kedalam persendian; hal ini merupakan gejala khas pada inflamasi gout (Gambar 2).

Beberapa hal penting dalam peran asam urat terhadap sistem imun ialah tinjauan terhadap konsep vaksin dan ajuvan. Telah lama dipahami bahwa vaksinasi terhadap organisme dengan menggunakan antigen ialah untuk menginduksi toleransi suatu respons imun. Untuk dapat menghasilkan respons imun, antigen harus dimasukkan kedalam ajuvan. Telah dikenal sejumlah ajuvan, seperti mikobakterium dan liposakarida, tetapi sampai saat ini mekanisme ajuvan menstimulasi respons imun belum jelas dipahami. Saat ini diketahui bahwa banyak ajuvan bekerja melalui Tolllike receptors (TLRs), yang merupakan ba- 
gian dari sistem imun yang mengenal struktur daerah molekul yang ditemukan pada bakteri tetapi tidak ditemukan pada sel mamalia; hal ini dikenal sebagai pathogen associated molecular pattern. ${ }^{27}$ Dengan demikian sistem imun memiliki kapasitas untuk mengenal antigen asing yang belum pernah bertemu sebelumnya. TLRs berperan dalam memberikan sinyal ajuvan kepada antigen-presenting cells (APCs), sebagai contoh: sel dendritik, makrofag dan sel B. APCs merupakan antigen dalam mengatur aktivasi TLRs tidak hanya de- ngan adanya antigen pada molekul MHC tetapi juga mengatur sejumlah costimulatory molecules seperti CD86. Costimulatory molecules memberikan sinyal kedua dalam kordinasi dengan molekul antigenbound $M H C$, yang menginduksi respons sel T. Bila sinyal kedua tidak ada, maka peristiwa pemaparan antigen dikenal sebagai 'palsu' oleh sel T dan lebih mengakibatkan efek toleransi dari pada efek stimulasi. Salah satu ajuvan yang dapat meningkatkan aktivitas sel $\mathrm{T}$ ialah sel-sel yang terdapat pada sitosol sel yang mati atau rusak.

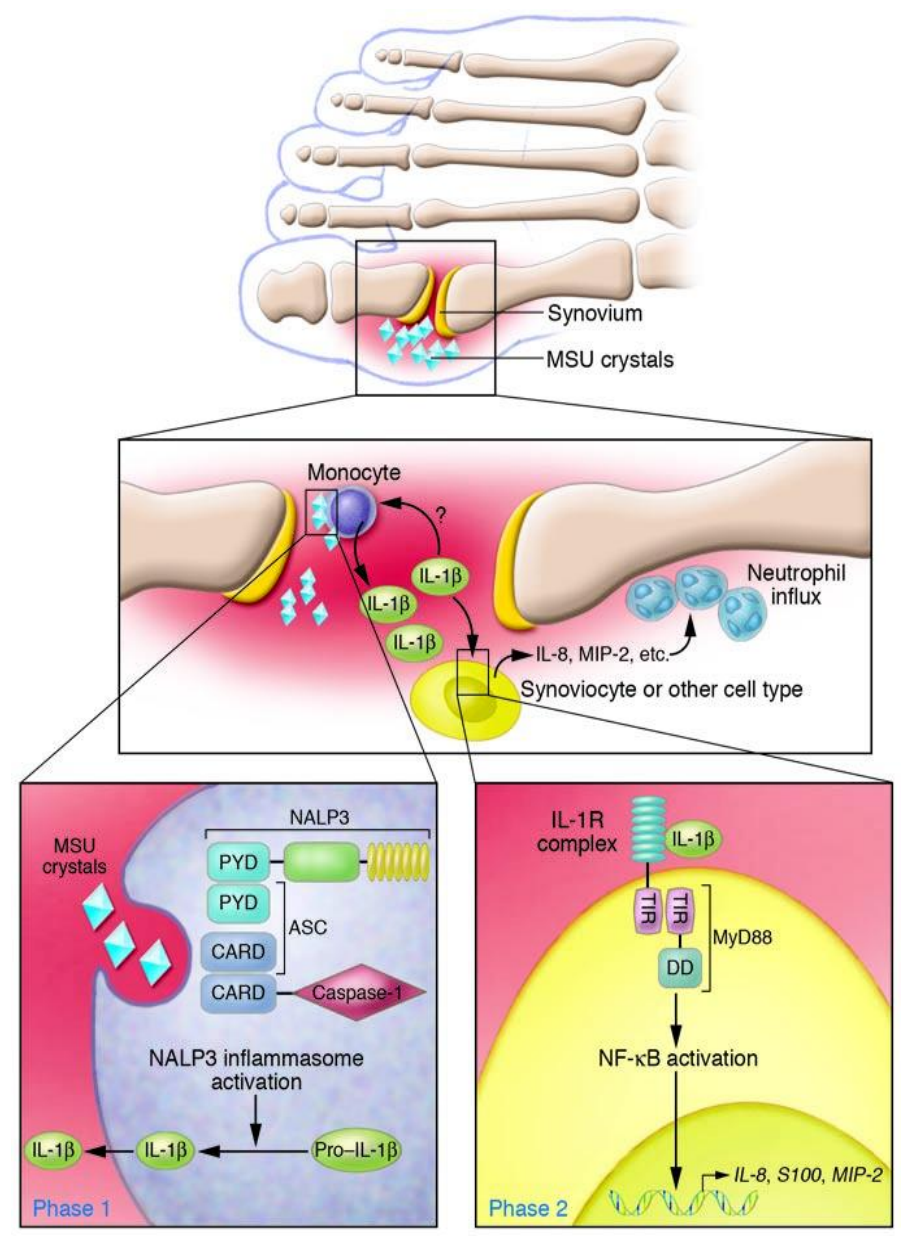

Gambar 2. Peran IL-1 $\beta$ pada inflamasi gout. Pada fase 1, kristal MSU masuk ke dalam ruang sendi bersama monosit dan mengaktivasi inflamasom NALP3 (Gambar 2 kiri bawah). Aktivasi NALP3 menyebab-kan aktivasi adaptor ASC dan caspase-1 melalui interaksi pyryine domain (PYD-PYD) dan caspase-recruitment domain (CARD-CARD) yang menghasilkan matu-rasi pro IL-1 $\beta$ menjadi bentuk aktif IL- $1 \beta$. Pada fase 2 , IL-1 $\beta$ akan mengaktivasi kompleks IL-1R untuk merekrut MyD88 melalui interaksi homotipik TIR-TIR (Gambar 2 kanan bawah). Proses ini akan menyebabkan aktivasi nuclear factor- $\kappa B(\mathrm{NF}-\kappa \mathrm{B})$ yang akan menggerakkan trans-kripsi kemokin merekrut neutrofil seperti IL-8, S100 atau macrophage in-flammatory protein 2 (MIP-2). Pada fase 2 (Gambar 2 kanan bawah) tampak apoptosisassociated speck-like protein (ASC) yang mengandung CARD, death domain (DD) dan PYD. Sumber: Martinon et al, 2006. ${ }^{24-26}$ 
Matzinger (1990) menyatakan bahwa kerusakan sel akibat trauma atau infeksi virus membutuhkan suatu sinyal ke sistim imun, untuk memperoleh suatu respons terhadap masuknya agen infeksi atau dibutuhkan suatu sinyal untuk pembersihan sisa-sisa sel yang mengalami nekrosis. ${ }^{27-29}$ Matzinger menciptakan istilah sinyal berbahaya (danger signal) untuk molekul yang dapat melakukan fungsi tersebut namun identitas sinyal tersebut sampai saat ini belum diketahui secara jelas. Telah dipahami bahwa program kematian sel merupakan proses awal terjadinya degradasi purin yang menyebabkan produksi asam urat meningkat (proses yang terjadi pada tumor lysis syndrome). Dengan demikian pada sel-sel yang mati kadar asam urat setempat secara cepat mengalami peningkatan dan selanjutnya asam urat bertindak sebagai sinyal berbahaya (Gambar 3). ${ }^{30}$

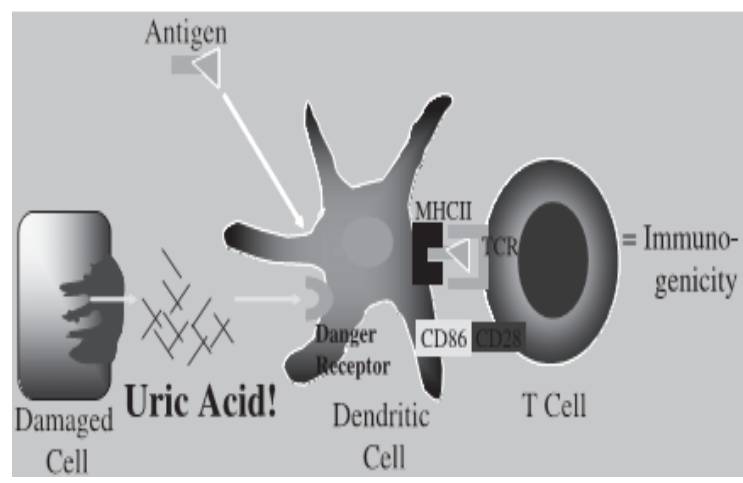

Gambar 3. Asam urat merupakan sinyal berbahaya yang bekerja sebagai adjuvan endogen bila jaringan mengalami cedera. Sumber: Pillinger et al, 2007. ${ }^{18}$

Kadar asam urat $>7 \mathrm{mg} / \mathrm{dL}$ dapat menyebabkan pembentukan kristal asam urat pada persendian dan daerah lainnya. Pembentukan kristal mengakibatkan terjadinya proses inflamasi yang melibatkan beberapa mekanisme. Terdapatnya kristal di dalam persendian akan mestimulasi sinyal inflamasi yang bercabang dua. Aktivasi komplemen menghasilkan pembentukan kemoatraktan seperti C5a yang mengaktivasi dan menarik neutrofil. Neutrofil akan ditolak oleh pembuluh darah jika sel-sel endotel vaskuler tidak diaktivasi oleh sitokin yang dihasilkan oleh makrofag seperti IL-1, TNF- $\alpha$ dan IL-6. Hasil penelitian saat ini memberikan pemahaman terhadap mekanisme bagaimana kristal asam urat mengaktivasi makrofag, terutama peran dari inflamasom NALP3 (NACHT, LRR dan pyrin domain-containing protein) yang merupakan suatu struktur yang memediasi pembentukan IL-1. Awalnya IL-1 disintesis sebagai pro-molekul dan membutuhkan pemecahan untuk menjadi aktif oleh caspase$1 .^{31-33}$

Sebagian besar inflamasom terdiri atas beberapa molekul dan biasanya termasuk satu atau beberapa molekul dari famili NALP. NALP yang mengalami mutasi berhubungan dengan sejumlah penyakit autoimun, penyakit autoinflamasi atau keduanya. Sebagai contoh mutasi pada NALP1 telah ditunjukkan berhubungan dengan vitiligo autoimun yang berkaitan dengan sejumlah penyakit autoimun. Sebaliknya, mutasi dapat menyebabkan hiperaktivitas NALP3 yang telah diidentifikasi sebagai penyebab penyakit, antara lain familial cold autoinflammatory disease. Inflamasom berperan penting dalam pengaturan proses inflamasi. Martinon et $\mathrm{al}^{24}$ menunjukkan adanya kemampuan asam urat untuk menstimulasi inflamasom NALP3 yang menyebabkan produksi IL-1 dan TNF- $\alpha$, sedangkan MyD88 merupakan molekul yang mentransmisi sinyal TLR intrasel, yang berperan penting dalam mengaktivasi inflamasom NALP3 dan respons sinyal autohumoral kedua untuk menyekresi IL-1 (Gambar 4). ${ }^{24,34}$

Sel-sel yang mengalami inflamasi apabila terpapar dengan kristal asam urat akan mengaktivasi sejumlah molekul sinyal intrasel lainnya yaitu MAP kinase dan NF- $\kappa \mathrm{B}$ dengan menghasilkan sitokin proinflamasi seperti IL-8. ${ }^{33,35}$ Endapan kristal monosodium urat monohidrat (MSU) pada persendian dan jaringan lunak bila terlepas dapat menyebabkan inflamasi akut. ${ }^{36,-37}$ Kristal MSU dapat menginduksi berbagai sitokin dan kemokin seperti $\mathrm{TNF} \alpha$, Il-1 $\beta$, IL-6, CXCL8 (IL-8), dan CXCL1 (growthrelated oncogene $\alpha){ }^{37-40 .}$ 


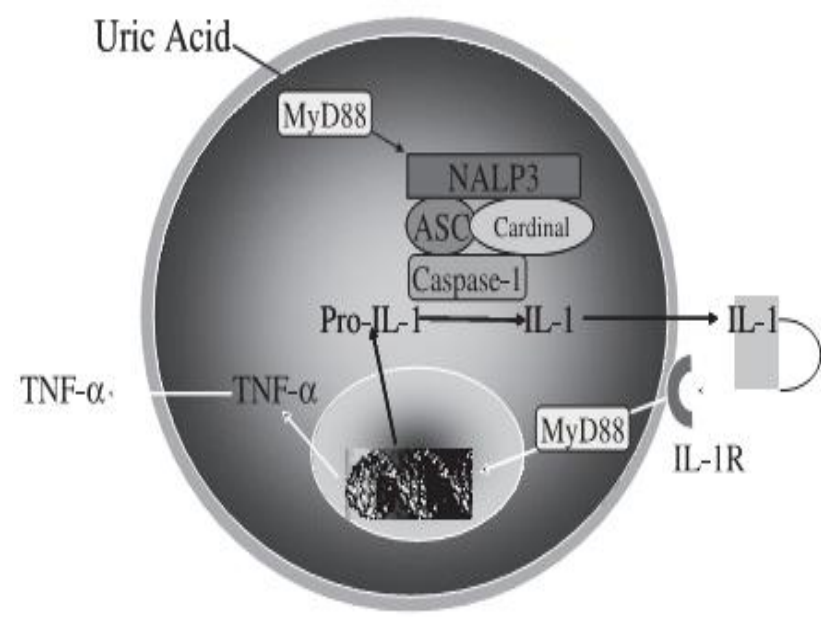

Gambar 4. Inflamasom NALP3: makrofag penghasil Il-1 untuk sekresi seluler. Sumber: Pillinger et al, 2007. ${ }^{18}$

\section{SIMPULAN}

Hiperurisemia dapat menyebabkan pengendapan monosodium urat (MSU) pada cairan sendi, tulang, kulit, tendon dan jaringan lunak lainnya. Kristal MSU dapat menginduksi berbagai sitokin dan kemokin seperti TNF $\alpha$, IL-1 $\beta$, IL-6, IL-8 dan growth-related oncogene- $\alpha$. Pengendapan kristal MSU pada persendian dan jaringan periartikuler berhubungan dengan gangguan autoinflamasi yang dikenal sebagai gout.

\section{DAFTAR PUSTAKA}

1. Shekkariz B, Stoller ML. Uric acid nephrolithiasis: Current concepts and controversies. J.Urol. 2002;168:130714.

2. Li EK. A review of aetiology and treatment. Hongkong Mes J. 2004;10:26170.

3. Wortmann RL. Disorder of purin and pyrimidine metabolism. In: Faucy AS, Braunwald F, Isselbacher KJ, editors. Harrison's Principles of Internal Medicine (Sixteenth Edition). New York: McGraw-Hill, 2001;p.2308-13.

4. Dincer HE, Dincer AP, Levinson DJ. Asymptomatic hyperuricemia treat or no to treat. Cleveland Clinic Journal of Medicine. 2002;69:594-608.

5. Qasi Y, Lohr JW. Hyperuricemia, eMedicine Nephrology. [homepage opn the internet] 2005. Nodate [cited 2010 May 10]. Available from: http:// emedicine.medscape.com/article/24176 7-overview.

6. Ruilope LM, Puig JG. Hyperuricemia and Renal Function. Current Hypertension Reports. 2001;3:197-202.

7. Wortmann RL. Recent advances in the management of gout and hyperuricemia. Curr Opin Rheumatol. 2005; 17:319-24.

8. Ghei M, Mihailescu M, Levinson $D$. Pathogenesis of hyperuricemia. Current Rheumatology Reports. 2002;4:270-4.

9. Silbernagl S, Lang F. Color Atlas of Pathophysiology. Stuttgart: Thieme Flexibook; 2000.

10. Niskanen LK, Laaksonen DE, Nyyssonen $\mathrm{K}$, Alfthan $\mathrm{G}$, Laaka $\mathrm{H}$, Laaka $\mathrm{T}$. Uric acid levels a risk factor for cardiovascular and all-cause mortality in middle aged men. Arch Inter Med. 2004;164:1546-51.

11. Mandell BF. Hyperuricemia and gout: a reign of complacency. Cleveland Clinic Journal of Medicine. 2002;69:589-93.

12. Cohen MG, Emmerson BT. Gout. In: Klippel JH, Dieppe PA, editors. Rheumatology Vol 2 (First Edition). Boston: Mosby, 1994; p.121-6.

13. Feig DI, Kang DH, Johnson RJ. Uric acid and cardiovascular risk. N Eng $\mathbf{J}$ Med. 2008;359: 1811-21.

14. Heinig M, Johnson RJ. Role of uric acid in hypertension, renal disease and metabolic syndrome. Cleveland Clinic Journal of Medicine. 2006;73(12): 1059-1064.

15. Hayden MR, Tyagi SC. Uric acid: A new look at an old risk marker for cardiovascular disease, metabolic syndrome, and type 2 diabetes mellitus: the urate redox shuttle. Nutr Metab (Lond). 2004;1:10.

16. Strazzulo YP, Puig JG. Uric acid and oxidative stress: relative impact on cardiovascular risk? Nutr Metab Cardiovasc Dis. 2007;17:409-14.

17. Bulakumar P, Sharma $R$, Kalia AN, Singh M. Hyperuricemia: Is it a risk factor for vascular endothelial dysfunction and associated cardiovascular disorders? Current Hypertension Review. 2009;5:1-6.

18. Pillinger MH, Rosenthal P, Abeles AM. 
Hyperuricemia and Gout. Bulletin of the NYU Hospital for Joint Diseases. 2007;65(3):215-21.

19. Shi Y, Evans JE, Rock KL. Molecular identification of a danger signal that alerts the immune system to dying cells. Nature. 2003;425(6957):516-21.

20. Gersch MS, Johnson RJ. Uric acid and immune response. Nephrology Dialysis Transplantation. 2006;21(11):3046-47.

21. Schnare M, Rollinghoff M, Qureshi S. Toll-like receptors: sentinels of host defence against bacterial infection. Int Arch Allergy Immunol. 2006;139:75-85.

22. Kanevets U, Sharma K, Dresser K, Shi Y. A Role of IgM antibodies in monosodium urate crystal formation and associated adjuvanticity. J. Immunol. 2009;182;1912-1918.

23. Behrens MD, Wagner WM, Krco CJ, Erskine CL, Kalli KR, Krempski J, et al. The endogenous danger signal, crystalline uric acid, signals for enhanced antibody immunity. Blood. 2008;11:1472-1479.

24. Martinon F, Petrilli V, Mayor A, Tardivel A, Tschopp J. Goutassociated uric acid crystals activate the NALP3 inflammasome. Nature. 2006;440: 237-41.

25. Chen CJ, Shi Y, Hearn A, Fitzgerald K, Golenbock D, Reed G, et al. MyD88dependent IL-1 receptor signaling is essential for gouty inflammation stimulated by monosodium urate crystals. J Clin Invest. 2006;116:2262-71.

26. Liu-Bryan R, Pritzker K, Firestein GS, Terkeltaub R. TLR2 signaling in chondrocytes drives calcium pyrophosphate dihydrate and monosodium urate crystal-induced nitric oxide generation. J Immunol. 2005;174: 5016-23.

27. Janeway CA, Jr. Medzhitov R. Innate immune recognition. Annu Rev Immunol. 2002;20:197-216.

28. Gallucci S, Matzinger P. Danger signals: SOS to the immune system. Curr Opin Immunol. 2001;13(1):114-9.

29. Skoberne M, Beignon AS, Bhardwaj N. Danger signals: A time and space continuum. Trends Mol Med. 2004; 10(6):251-7.

30. Gasse P, Riteau N, Charron S, Girre S, Fick L, Petrilli $\mathbf{V}$ et al. Uric acid is a danger signal activating NALP3 inflammasome in lung injury inflammation and fibrosis. Am J Respire Crit Care Med. 2009;179:p.903-913.

31. Andrews NW. Membrane repair and immunological danger. EMBO. Rep 2005;6(9):826

32. Ogura Y, Sutterwala FS, Flavell RA. The inflammasome: First line of the immune response to cell stress. Cell. 2006;126(4):659-62.

33. Martinon F, Berns K, Tschopp J. The inflammasome: A molecular platform triggering activation of inflammatory caspase and processing of proIl- $\beta$. Mol Cell. 2002;10(2): 417-26.

34. Chen CJ, Shi Y, Hearn A, Fitzgerald K, Golenbock D, Reed G, et al. MyD88dependent IL-1 receptor signaling is essential for gouty inflammation stimulated by monosodium urate crystals. J Clin Invest. 2006;116: 2262-71

35. Liu R, O'Connel M, Johnson $K$. Extracellular signal-regulated kinase 1/extracellular signal-regulated kinase 2 mitogen-activated protein kinase signaling and activation o activator protein 1 and nuclear factor kappaB transcription factors play central roles in interleukin- 8 expression stimulated by monosodium urate and calcium pyrophosphate crystals in monocytic cells. Arthritis Rheum. 2000;43(5):893-903.

36. Choi HK, Mount DB, Reginato AM. Pathogenesis of gout. Ann Intern Med. 2005;143:499-516.

37. Terkeltaub R, Zachariae C, Santoro D, Martin J, Peveri P, Matsushima K. Monocyte-derived neutrophil chemotactic factor/interleukin-8 is a potential mediator of crystal-induced inflammation. Arthritis Rheum. 1991;34:894903.

38. Di Giovine FS, Malawista SE, Nuki G, Duff GW. Interleukin 1 (IL 1) as a mediator of crystal arthritis: stimulation of $\mathrm{T}$ cell and synovial fibroblast mitogenesis by urate crystal-induced IL 1 . J Immunol. 1987;138: 3213-8.

39. Di Giovine FS, Malawista SE, Thornton E, Duff GW. Urate crystals stimulate production of tumor necrosis factor $\alpha$ from human blood monocytes and synovial cells: cytokine mRNA and protein kinetics, and cellular distribu- 
110 Jurnal Biomedik, Volume 3, Nomor 2, Juli 2011, Hlm. 102-110

tion. J Clin Invest. 1991;87:1375-81.

a poised promoter architecture in

40. Liang MD, Zhang Y, McDevit D, Marecki S, Nikolajczyk BS. The monocytes. J Biol Chem. 2006;281: interleukin- $1 \beta$ gene is transcribed from 9227-37. 